\title{
The Impact of Corona Virus Outbreak Regarding the Large-Scale Social Restriction Policy on Economic Attitudes in Makassar
}

\author{
Dr. Patta Rapanna SE MSi ${ }^{1}$, Dr. Edy Jumady, S.E., M.Si ${ }^{1}$ \\ ${ }^{1}$ Lecturer of High School Economics Makassar, Indonesia \\ Correspondence: Dr. PattaRapanna SE MSi, Lecturer of High School Economics Makassar, Indonesia.
}

Received: June 30, 2020

Accepted: July 23, $2020 \quad$ Available online: August 5, 2020

doi:10.11114/ijsss.v8i5.4963

URL: https://doi.org/10.11114/ijsss.v8i5.4963

\begin{abstract}
Types of qualitative research through the phenomenological approach, the results showed that Corona virus outbreak affects all sectors, one of which is the economic factor where many people become victims of termination of employment from the company they work besides large-scale social restriction policies or lock down impacts the limited activities, especially the social and economic movements of the community, while the , this is because of many people who do not have a domicile letter because of displacement that is temporary (not settled), this condition affects social gaps, criminal figures, social jealousy, etc.
\end{abstract}

Keywords: policies, attitudes, economics, corona, social

\section{Introduction}

Corona virus OUTBREAK (Covid-19) is known to first spread in Wuhan, China, at the end of 2019. Since then, the virus has spread rapidly throughout the world, without exception to Indonesia. The World Health Agency (WHO) has also announced the outbreak of Corona as a global pandemic. This means that the same health problem threatens many countries. Because the spread is so fast, they cannot deny it until the Corona virus affects the global economy.

Indonesia's economic performance, especially in the city of Makassar, experienced the impact that makes economic condition and social community condition experienced finance Minister Sri MulyaniIndrawati said, the current global economic condition is very challenging. He also acknowledged that the worsening of global economic conditions would affect the economy of Indonesia. "We understand the global economic conditions are challenging. In addition, faced with the weakening of the economy, now coupled with the outbreak of Corona virus, "said Sri Mulyani in Jakarta, Monday $(2 / 3 / 2020)$. Its impact is not playful.

"If the duration of Covid-19 can be over 3 to 6 months, then lockdown, and international trade can drop below 30 percent, the flight drop up to 75 percent to 100 percent, then the scenario can become deeper, economic growth can be between 2.5 percent even 0 percent, " Papar Sri Mulyani.

Head of South Sulawesi trade service Andi Basalama said the value of export of commodities to China decreased because of Corona virus. He said it happened not only in South Sulawesi and Indonesia but also the world economy. "This Corona Virus affects us in the region

The spread of Corona virus in China is against the stopping of export of several seafood commodities from South Sulawesi to the land of bamboo blinds. Such as crabs, fish, seaweed, shrimp and fish eggs fly. A percentage of the initial export value of the first month of 2020 to China by 2 million US dollars compared to the previous year in the same month.

One policy taken by the Government of Makassar to suppress the spread of Corona viruses, the city government of Makassar made a policy that the social restriction of large-scale (PSBB) This policy means limiting the space of movement of people in activities.

\section{Questions}

1. How is the impact of a corona virus in Makassar

2. Government policy of Corona pandemic virus in Makassar

3. How the impact of a social restriction on large-scale social-economic activity in Makassar City 


\section{Foundation Theory}

\section{Definition of Corona Virus}

The Corona virus or Severe acute respiratory Syndrome coronavirus 2 (SARS-CoV-2) is a virus that attacks the respiratory system. They call the disease because of this viral infection COVID-19. Corona Virus can cause disruption of the respiratory system, acute pneumonia, until death.

Severe Acute Respiratory Syndrome coronavirus 2 (SARS-CoV-2) popularly known as Corona virus is an unknown corona virus contagious to humans. This Virus can attack anyone, whether babies, children, adults, elderly, pregnant women, and nursing mothers.

They call this viral infection COVID-19 and was first discovered in the city of Wuhan, China, at the end of December 2019. The Virus is contagious rapidly and has spread to other regions in China and to several countries, including Indonesia. Corona virus is a collection of viruses that can infect the respiratory system.

Most times, this virus only causes mild respiratory infections, such as flu. However, this virus can also cause severe respiratory infections, such as lung infections (pneumonia), Middle-East Respiratory Syndrome (MERS), and Severe Acute Respiratory Syndrome (SARS).

\section{A. Public Administration}

The public administration or formerly known as the State administration is essentially a form of administrative cooperation that is done by two or more people to achieve a common goal. Goal of the public administration itself is Public Service or public service. Public administration has studies on politics, law, social and management.

The task of the public administration is the policymaker or policy Maker known as the public policy. This means that these administrators create a policy with the aim of addressing issues in the public.

The organization will achieve its objectives with the support of tools, namely effective administration and efficient administration can give a prominent role for the success of an organization that ultimately leads to the prosperity and welfare of the people. The Administrator role is the agent of Change (Irawati, 2007).

\section{B. Public Policy}

Public policy is a government intervention that aims to alter the existing or influence the direction and pace of ongoing changes in society, to realize the desired conditions.

Lindlom in MeyziHeriyanto (2012) described the formulation of public policy as "a complex, analytical and political process to which there is no beginning or end the boundaries of which are most uncertain. Somehow a complex set for forces we call policy-making, all taken together, produce effect called policies ".

According to the Public Administration dictionary public Policy is a strategic utilization of existing resources to solve public or government problems. While Shafritz and russell provide a public policy definition of whatever a government does or not to do. Both authors stated that what they did is a response to a political issue. Another opinion says that public policy understanding is also revealed as one tactic and strategies geared towards achieving a goal. Therefore, he said a policy of loading 3 (three elements) is; Identification of the objectives to be achieved. Second, tactics or strategies of various measures to achieve the desired objectives, and third, provision of various inputs to allow the implementation of the actual performance of tactics or strategies.

Richard Layard (2005) in John F. Helliwell (2005) argues, trends in short-term commitments, and rising monetary and other linking appreciation to individual performance targets, especially short-term ones, may experience corrosive effects on trust and loyalty and create unhappiness.

\section{Economic Development}

I have long considered an accumulation of human capital that was an important factor in economic development. The results obtained in the initial set of regression are therefore somewhat disappointing: when a person runs the Cobb-Douglas implied specifications in Jess Benhabib, Mark M. Spiegel (1994) standard production functions that include human capital as a factor, the accumulation of human capital that failed to enter significantly in determining economic growth, and even entered with a negative point estimate.

More and better education is a prerequisite for rapid economic development around the world. Education stimulates economic growth and improves people's lives through many channels: by increasing the efficiency of force labor, by increasing democracy (Barro, 1997 in ThorvaldurGylfason, 2001) and creating better conditions for good governance, through improved health, by increasing equality (Aghion et al., 1999 in ThorvaldurGylfason, 2001).

An example, or model, a successful theory is the economic growth theory that Robert Solow and Edward Denison in 
(Robert E. Lucas, Jr., 1988) developed and applied to the twentieth century US experience. This theory will serve as the basis for further discussion in three ways: as an example of the form that a useful aggregative theory should take, as an opportunity to explain what theory this form can tell us that other types of theories can not be, and as a theory to economic development.

\section{Research Methods}

This research uses a phenomenological approach and is classified into qualitative descriptive research. The data sources in this study include: primary Data source, secondary Data source. While the Instrument research is the researcher itself. The data collection techniques used are: Interview technique, observation, documentation. Meanwhile, the data analysis techniques used are: data collection, data reduction, presenting data (display data), draw conclusions (drawing).

\section{Discussion}

The spread of Covid-19 is difficult to be dammed, no exception in South Sulawesi. Recorded as of Monday 30 March 2020, the positive amount of infected Corona reaches 50 people, people in monitoring (ODP) Approximately 630 people, and patients in monitoring (PDP) about 105 people. This is astounding, as it predicts the figure to continue increasing day by day.

Covid-19 not only threatens health but also economic stability in South Sulawesi .Reduced purchasing power, unavoidable termination of employment (Layoffs). Then followed by declining economic growth.

The city government of Makassar today more refers to the social distancing approach the government to take, besides the many Parties that urged alternative quarantine policy (lockdown).

Unfortunately, such urges have been little based on the obvious economic calculations and simulations.

Based on the results of studies conducted by the research team Logov Celebes which presents evidence in the measure of both schemes found that, through the territorial quarantine scheme for 1 month, estimated the economic growth of South Sulawesi year 2020 will be in the number 5.05 percent.

The corona pandemic that resulted in the economy in Makassar weakened to be the thing to be completed with the government. Looking at this phenomenon, economic observers say, amid situations like this the Government's dilemma in carrying out obligations on society.

"Whether to stimulate the economy or to seek health to withstand the rate of Corona viruses is increasingly impactful," said Arief R Pabettingi, chairman of DPD Indonesia Export company combined (GPEI) West Sulawesi on Fajar.co.id, Tuesday (31/3/2020).

According to the present condition, all potentials that can make the economy and trade passion feel affected by the corona virus. He claimed the Corona plague not onsly affected the economic crisis, also the financial, political, and humanity crisis.

"For example, the economic recession, the plummeted stock market, the weaker exchange rate, the foreign funds are increasing to the decline in the commodity prices of exports,".

Arief hopes that after this phenomenon has passed, the government can create policies that can stabilize the economy

"Such as tax deductions and interest rates, guaranteeing the continuity of trades after the virus has passed,"

It is very worrying, when the country must decide lockdown for a while. The economic impact for the lower middle group would be enormous. Revenue support their daily economies on that day. Inclusion becomes very vulnerable because when they do not work, their income is also not there. Similarly, for those working as ASN or formal agency employees, even though they do not work for two weeks because of work from home, their salary at the beginning of the next month remains intact.

If the condition is insoluble then informal officers, traders, small business, and the people who work as a person, they are very vulnerable to poverty. One day they did not work, so there was nothing to eat for that day and the ooclips.

Have little to think. These last days alone, online transport is silent. Their revenues dropped drastically because no one ordered.

So also the tourism sector is closed. Millions of people whose lives depend on the tourism sector become unemployed. Millions of managers and destination employees are idle. Millions of hotel employees are idle. Millions of souvenir craftsmen do not produce. Millions of souvenir material suppliers also stop giving supplies.

Owner and Clerk of food hawker stalls and souvenir shops stop working. The travel stops operations. Hundreds of thousands of transportation service providers, driver and tourist bus crews, and idle tour guides.

Likewise, schools and campuses over the next two weeks are closed. This will negatively affect all people whose lives 
depend heavily on school and campus. Hundreds of thousands of people who trade in schools and campuses don't work. The motorcycle taxi driver who drove each day and picked up students, students, teachers, and TU employees did not work. Teachers and honorary lecturers do not teach. Suppliyer Whole school equipment and lectures can no longer work.

Remarkably, for the economic impact of the spread of Corona viruses in the South Sulawesi region. It threatens millions of people to be unemployment for a minimum of two weeks. However, is it only two weeks? ALL government decisions depend heavily on data on the increase or decrease of the affected person's data.

The seafood traders from Galesong District Takalar For example, they have trouble to make a sale in the suspect due to the impact of the corona virus outbreak. A merchant from Galesong district of Takalar District, South Sulawesi ,Kartini Razak at Takalar, revealed the difficulties of selling seafood after corona virus issues arose. There are no buyers or deliveries. They trade some types of seafood in the form of seaweed, sea cucumber to fish.

"There is no buyer, because the seafood is much to China and there are many requests for comparison from Korea and Japan," he said.

Kartini stated if there is a purchase of seafood, the price is cheap. Like the seaweed was before a corona virus outbreak costs 24,000 per $\mathrm{kg}$, it is down to 18,000 per $\mathrm{kg}$.

In fact, he said, the price taken in the field precisely around the island of Maluku reaches $\mathrm{Rp} .17000$. The result resulted in a loss of about 50 million. The reason for reaching the island requires a lot of fuel fare. The current price in the value gradually improved even though it is not stable, "the last price of seaweed is already Rp. $20 \mathrm{RB}$, but this is not normal because the cost of the purchase in the seaweed farmer remained as usual, not down," he said.

In line with Riswandi, a hawker from Galesong Takalar Regency, claimed to be struggling to find a buyer. The result was only stuck, and not a few sea cucumbers who bought the balance shrank.

"If a lot of searchers are many on the island, but that buy is hard. If there is a cheap price of the buy. Our result is a loss. This is so after corona viruses. He said there is no buyer and delivery to China for a while, "said Wandi, the Spoken .

They also know some types of sea cucumbers as Koro, Binti, Nenas, and Kapok and each size is large or small. It also differentiates the selling price of this item on wet or dry status when sold. Wandi said the price of all kinds of sea cucumber is down about Rp. 50,000-60,000 per kg, such as a sea cucumber as the sea cucumber with the highest price is often priced at Rp. 500,000 per kg, now only Rp. 435,000 per Kg.

"We hope this corona virus does not continue to plague because of its impact to our seafood merchants and also small fishermen," he said.

\section{B. Indonesian Government policy pandemic the Corona virus it implements whose implementationit in the city of Makassar}

President JokoWidodo announced he has signed a government regulation instead of Law (Perppu) published to mitigate the impact of the Corona virus pandemic (Covid-19) in Indonesia.

The details of government policy in the handling of pandemic Covid-19 under the stipulated in the new Perppu are as follows.

\section{Additional spending of Rp405,1 trillion in AP2020 BN}

The government increased the budget and financing 2020 for Covid- 19 for the handling of Rp405, 1 trillion. The addition of the budget is allocated to several sectors, namely: for the health expenditure allocated Rp75 trillion for social protection budget allocated costs RP110 trillion for the tax incentives and stimulus the people's Business credit (KUR) allocated Rp70,1 trillion for the financing of national economic recovery programs, including the restructuring of credit and the guarantee and financing of business, especially SMES, allocated Rp150 trillion.

2. Budget priorities in the health sector

Under the information on the budget, spending Rp75 trillion in the health field will be prioritized for fulfillmenting several needs, namely: protection of health workers, especially the purchase of personal protective equipment (PPE) purchase tools such as test kits, reagents, ventilators, hand sanitizers and other 132 upgrades for the Covid-19 referral hospital, including the athletes ' guest house incentives for doctors, nurses and hospital personnel (specialist doctors incentives RP15 million/month, general practitioner RP10 million/month, nurse Rp7,5 million/month, and other medical personnel RP5 million/month). Death benefit Rp300 million medical personnel handling other health problems.

\section{Budget priorities for social protection}

According to the rate, the government will prioritize the allocation for social protection when pandemic corona to several programs, such as Family wishes Program (PKH), groceries cards, Prakerja cards, and electricity tariff waivers. The 
details are: The number of beneficiaries of PKH plus from 9.2 million to 10 million families in the number of beneficiaries of the groceries card is also added from 15.2 million to 20 million people electricity fee exemption 3 months for 24 million electric customers $450 \mathrm{VA}$ and 50 percent discount for 7 million customers $900 \mathrm{VA}$. It raised the budget of the Prakerja card from RP10 trillion to RP20 trillion to 5.6 million people affected by layoffs, informal workers and micro-and small-business actors. The beneficiaries of this program will receive a postwar incentive of Rp 600 thousand, with a training fee of 1 million. Logistics and basic needs of RP25 trillion. Also read: Free electricity tariff mechanism \& three months discount.

\section{Budget priorities for venture world incentives}

The Government provides several incentives as an economic stimulus to SMES and businesses, which is: free PPh 21 for workers processing industry sector with a maximum income of RP200 million (during the year) Import VAT exemption for taxpayers then import export Goals (KITE), especially KITE from the small and medium industries, in 19 certain sectors reduction of Income tax of 25 percent for the taxpayers then Import Export Purpose (KITE), especially small middle-sized industries, on the specific sector of the acceleration of VAT restitution for 19 specific sectors to safeguard the liquidity of businesses declining tariff $\mathrm{PPh}$ agency from 25 percent to 22 percent delays in principle and interest payments for all affected KUR schemes COVID-19 for 6 months.

\section{Priority in non-fiscal fields}

The government enforces several policies in the non-fiscal field to guarantee the availability of goods required, including industrial raw materials. Several such policies are: simplification of limited restrictions (cartas) export simplification of limited restrictions (Lartas Import) acceleration of the Export-import service through national logistic ecosystem.

\section{Revised of APBN deficit limit}

Perrpu the current rate signed that also set a revision to the maximum limit of the budget APBN to above 3 percent. It enforces relaxation of the maximal deficit of this Budget In the years between 2020, 2021 and 2022. According to the budget, the Government is trying to expect the predicted APBN deficit can swell up to 5.07 percent. He confirms fiscal discipline maximum 3 percent deficit will be re-applied in 2023.

\section{Monetary policy}

The Bank of Indonesia and the Financial Services Authority sought to optimize the government and financial sector in order to provide the power to support and maintain the stability of the national economy. According to him, BI has issued a monetary stimulus policy through a triple intervention intensity policy, and lowers the mandatory current ratio of foreign exchange to conventional banks. "It also expands the underlying transactions for foreign investors and the use of global and domestic custodial banks for investment activities," said the In addition, the word, the OJK also publishes several policies, namely: provision of waivers and/or delays in the payment of creditor leading up to RP10 billion, including for SMES and informal workers, a maximum of 1 year providing waivers and/or delays in credit payments or leasing without ceiling restrictions, according to the ability of debtors and agreed with banks or leasing agencies.

The city government of Makassar as the provincial capital of South Sulawesi in implementing a policy related to Corona virus outbreak is referring to the national policy of the Indonesian Government, the form of activity is to prepare long-term handling, to deal with the impact of the virus corona or Garry 19.

They revealed it Pj mayor of Makassar, Iqbal Suhaeb. He said, will I recover economically the most affected sector for Garry 19.

"We are more into the economic recovery, because if Corona virus we already broke the chain, our bodies are immune and do not spread anymore to others, then much more important is the economic recovery," he said, Wednesday (1/4/2020).

We refocusing. We ask the social service; we ask the Manpower Office to develop programs related to the handling of Garry 19, said Iqbal.

Alluded to about the company's not the way, he admitted there was already an agreement with the business unit actors, that as long as the employees did not enter, they only received a salary of 50 percent, he said continue.

"We have also done incentive policies, both tax incentives, facility incentives that facilitate entrepreneurs," he explained.

While on the side of the businessman having their own response to corona threats, Indonesia Hotel and Restaurant Association (PHRI) of South Sulawesi Branch said the spread of the corona virus outbreak has suppressed their members ' efforts. For the field of hospitality, chairman of PHRI South Sulawesi Anggiat Sinaga said the plague has made the level of the room is dropped to remaining 8 percent- 10 percent only.

Because of that problem, many members planned employees. Hospitality entrepreneurs have no choice but the policy. "Seeing occupancy which is only 8 percent-10 percent and there is absolutely no event in the hotels, there is no 
option other than laying out employees for two months. Hopefully, this storm soon passed so they return to work,"said Anggiat in Makasar. Because of the policy, they ask the connection to take leave without being paid alias unpaid leave. He made sure there was no planned. If the situation returns to normal, then the employee can return to work again.

Not only the hotel, said Anggiat, the same situation also experienced the business of restaurants, restaurant, Resto and café-Cafe.

\section{The impact of a sociala social restriction on large-scale social-economicsocial, economic activity in Makassar City}

There are social restrictions on the public that make the condition of the community experiencing a loss so that in its application can not be done strictly, many conditions and economic problems cause the community to still force the activity, in fact there is a lot of quarrels with the officers in the field, from one side of the government officials must enforce the rules, but from the other side of the community still insist on going to work to fulfill the needs of life, this condition makes the community to try to penetrate the care, besides many companies that restrict their work activity, small companies, and large companies are experiencing the scan of pandemic corona and social restrictions on large-scale, community conditions amid the fear of a corona virus outbreak forced most of the community's activities in the home and tended to save, the interest of the public to shop down Dractis so that companies that produce secondary needs, such as clothing products, furniture, restaurants, hotels experiencing a very dracic decline so that forcing the company to take steps to disconnection employment or contact employees until the condition Garry 19 Ends.

\section{Conclusion}

Corona virus outbreak spread in the world also impacts to Makassar city where various sectors feel the impact, condition pandemic virus Corona 19 cause economic conditions, social, political underdevelopment, thousands of employees and workers are experiencing conditions that require them to make economic savings, because many employees stopped from where they work, while those who are still active work not full work, meaning that during the time not pandemic Corona employees work 26 days a month, then during pandemic Corona has not decreased then they are only a few 15 days in a month. For that it was born economic assistance policy for the community that experienced the downturn, other than that the social restriction of large-scale making the space of the movement of community activities caused many miss communication occurs between this because the information and rules related to the restriction of community activities has not been socialized.

\section{References}

Irawati. (2007). Renewal of administration and bureaucracy (an Era of Change). the Civil Journal edition I/May 2007.

Jess, B., \&Mark, M. S. (1994). The role of human capital in economic development Evidence from aggregate cross-country data. Journal of Monetary Economics, 34. https://doi.org/10.1016/0304-3932(94)90047-7

JoAnn, C. C., \& James, W. C. (2004). Economic Development: Changing the Policy to Support Entrepreneurship. Academy of Entrepreneurship Journal, 10(2), 2004.

John, F. H. (2005). Well-Being, Social Capital and Public Policy: What's New? National Bureau of Economic Research 2005.

Meyzi, H. (2012). Outer Island development Policy formulation. Journal of Public Policy, 3(1), 1-57.

Rakhmat,M. S. (2005). Public administration reform to a Democratic regional government. Journal of Public Administration, 1(1), 2005.

Robert, E. L. J. (1988). On the Mechanics of Economic Development.Journal of Monetary Economics, $22,3-42$. North-Holland. https://doi.org/10.1016/0304-3932(88)90168-7

Thorvaldur, G. (2001). Natural resources, education, and economic development. European Economic Review.

\section{Copyrights}

Copyright for this article is retained by the author(s), with first publication rights granted to the journal.

This is an open-access article distributed under the terms and conditions of the Creative Commons Attribution license which permits unrestricted use, distribution, and reproduction in any medium, provided the original work is properly cited. 